\title{
Utilization of low-quality roughage by Bos taurus and Bos indicus cattle
}

\section{The effect of rumen-degradable nitrogen and sulphur on voluntary food intake and rumen characteristics}

\author{
BY R. A. HUNTER AND B. D. SIEBERT* \\ CSIRO, Division of Tropical Animal Science, Tropical Cattle Research Centre, \\ Rockhampton, Queensland 4701, Australia
}

(Received 26th June 1984 - Accepted 21 December 1984)

1. In a number of experiments voluntary food intake of three low-quality roughages, either alone or supplemented with rumen-degradable nitrogen and sulphur and minerals, was measured in Brahman (Bos indicus) and Hereford (Bos taurus) steers. The chaffed hays were Spear grass (Heteropogon contortus) (6.2 g N/kg organic matter (OM)), Pangola grass (Digitaria decumbens) $(7 \cdot 9 \mathrm{~g} \mathrm{~N} / \mathrm{kg} \mathrm{OM})$, and Pangola grass $(12 \cdot 0 \mathrm{~g} \mathrm{~N} / \mathrm{kg} \mathrm{OM})$. Rumen characteristics relating to rate of fluid outflow from the rumen were also determined.

2. There was no significant difference between breeds in the dry-matter intakes of the unsupplemented diets which ranged from 11.3 to $17.8 \mathrm{~g} / \mathrm{kg}$ body-weight (BW) by Herefords and from 11.8 to $16 \cdot 1 \mathrm{~g} / \mathrm{kg} \mathrm{BW} \mathrm{by}$ Brahmans.

3. Supplementation of Spear grass with $\mathrm{N}$ and $\mathrm{S}$ significantly $(P<0.05)$ increased intake by Herefords $(24 \%)$ but not by Brahmans. When the lower-N Pangola grass was supplemented there was a significant increase in intake by both breeds with the magnitude of the response in Herefords $(42 \%)(P<0.001)$ being greater than that in Brahmans $(15 \%)(P<0.05)$. The intakes of both the supplemented Spear grass and the lower- $\mathrm{N}$ Pangola diets were significantly $(P<0-05)$ greater by Herefords than Brahmans. There was no breed difference in intake when the higher-N Pangola grass was supplemented. Both breeds recorded an $8 \%$ intake response to supplementation, although the increase was only significant $(P<0.05)$ in Herefords.

4. The mean retention time of fluid in the rumen on the unsupplemented Pangola grass diet of lower $\mathrm{N}$ content was $12.7 \mathrm{~h}$ in Brahmans compared with $17.5 \mathrm{~h}$ in Herefords $(P<0.01)$. When the higher-N Pangola was fed, both alone and supplemented, the mean retention times were similar on both diets $(10.5$ and $9.9 \mathrm{~h}$ for Herefords; 9.5 and $8.1 \mathrm{~h}$ for Brahmans for unsupplemented and supplemented diets respectively).

5. Plasma urea concentrations were higher in Brahmans than in Herefords on all diets. Rumen ammonia concentrations were signifiçantly $(P<0.001)$ higher in Brahmans than Herefords when the lower-N Pangola grass diet was unsupplemented.

6. The intakes and the variable intake responses to supplementation between breeds and diets are discussed in relation to a number of animal and dietary factors.

It has been established that in the absence of disease, climatic and parasitic stress, Bos taurus type steers and bulls have higher voluntary food intakes of high and medium quality roughage diets than their Bos indicus counterparts (Frisch \& Vercoe, 1969, 1977). The relative intakes of the two types of cattle when the diet is of poor quality and does not provide sufficient nitrogen for normal rumen function is not known. In the previous study, Hunter \& Siebert (1985) showed that on such diets, fed ad lib., the rate of rumen digestion of feed in nylon bags was greater in Brahman (Bos indicus) than in Hereford (Bos taurus) steers and that this was associated with higher rumen ammonia concentrations in Brahmans. When supplementary $N$ and sulphur were added to the rumen, the difference between breeds in digestion rate disappeared. The present paper reports the voluntary food intakes and some digesta flow characteristics of the same Brahman and Hereford steers when the same and other low-quality hays with different chemical compositions were fed alone or supplemented with rumen-degradable $\mathrm{N}$ and $\mathrm{S}$.

* Present address: CSIRO, Division of Animal Production, Glen Osmond, South Australia. 


\section{MATERIALS AND METHODS \\ Expt 1. Voluntary food intake}

The experimental details are given previously (Hunter \& Siebert, 1985). Briefly, six Hereford (Bos taurus) and six Brahman (Bos indicus) steers, all of approximately $300 \mathrm{~kg}$ live weight, were fed ad lib. Pangola grass (Digitaria decumbens) and Spear grass (Heteropogon contortus) either alone or supplemented with rumen-soluble $\mathbf{N}$ and $\mathbf{S}$ and minerals. Intakes were recorded daily.

\section{Expt 2. Digestion and rumen characteristics of steers fed on Pangola grass}

Chaffed Pangola grass hay $(7.9 \mathrm{~g} \mathrm{~N} / \mathrm{kg}$ organic matter $(\mathrm{OM}))$ from the same harvest as that given in Expt 1 was given ad lib. in two experimental periods with three Hereford and three Brahman steers being used in each period. These were the same animals that were used in Expt 1 . The periods of $19 \mathrm{~d}$ duration consisted of $10 \mathrm{~d}$ preliminary feeding, $8 \mathrm{~d}$ during which faeces and urine were collected for measurement of digestibility and $1 \mathrm{~d}$ during which samples of rumen fluid were collected at intervals of $2 \mathrm{~h}$ for $14 \mathrm{~h}$ for measurement of rumen volume, mean retention time and rumen dilution rate by reference to the liquid-phase marker chromium-EDTA (Weston \& Hogan, 1967). The steers were in metabolism crates for the final $11 \mathrm{~d}$ of the feeding period and were offered an equal portion of the day's feed allotment hourly by automatic feeding devices. Cr-EDTA (approximately $300 \mathrm{mg} / \mathrm{d}$ ) was infused continuously into the rumen by peristaltic pump for $3 \mathrm{~d}$. Infusion was then stopped and the first sample of rumen fluid taken $2 \mathrm{~h}$ later. The equation of Weston \& Hogan (1967) presumes that animals are in 'steady state' which means restricted quantities of feed are offered in equal portions at regular intervals. The steers, fed ad lib., were not in the strictest sense in 'steady state' because a constant amount of feed was not eaten each hour. However, use of the automatic feeding devices enabled steady-state conditions to be approached. Moreover, since the feeding behavour of all steers was similar to that described by Hunter \& Siebert (1980), valid comparisons between genotypes could be made.

\section{Expt 3. Effect of supplementation with $N$ and $S$ on intake, digestion and rumen characteristics of steers fed on Pangola grass}

Chaffed Pangola grass ( $12.0 \mathrm{~g} \mathrm{~N} / \mathrm{kg} \mathrm{OM})$ hay from a different harvest from that used in the previous two experiments was fed ad lib. both alone and supplemented with $90 \mathrm{~g}$ urea and $4 \cdot 1 \mathrm{~g} \mathrm{~S}$ as dilute sulphuric acid. The feed was given hourly using automatic feeding devices. The experiment was cross-over in design. As with Expt 2, the same twelve steers were divided into two groups with three Brahmans and three Herefords in each group. In the first period with each group, two Brahman and two Hereford steers were fed on the unsupplemented diet and one steer of each breed on the supplemented diet. In the second period the treatments were reversed. A solution of urea and $\mathrm{S}$ was mixed with the feed. Other experimental details are the same as in Expt 2, with the exception that an additional portion of rumen fluid that was collected twice hourly for $14 \mathrm{~h}$ was acidified with $\mathrm{H}_{2} \mathrm{SO}_{4}$ and composited at $-15^{\circ}$ for $\mathrm{NH}_{3}$ analysis.

\section{Chemical analysis}

Dry matter (DM) was determined after oven drying at $80^{\circ}$ to constant weight and $\mathrm{OM}$ after incineration at $600^{\circ}$ for at least $3 \mathrm{~h}$. $\mathrm{N}$ concentration, after a Kjeldahl digestion, and $\mathrm{NH}_{3}$ concentration in acidified rumen fluid were determined using an autoanalyzer by the method of Logsdon (1960). Urea-N concentration in plasma was determined using an autoanalyser with the Technicon modification (Clinical method, No. 01) of the method of Marsh et al. 1965). Cr concentration was determined by atomic-absorption spectroscopy (Binnerts $e t$ 
Table1. Chemical composition of feeds $(\mathrm{g} / \mathrm{kg}$ organic matter $(O M))$

\begin{tabular}{lccc}
\hline \hline Expt no.... & $\begin{array}{c}\text { Spear grass } \\
\text { (Heteropogon } \\
\text { contortus) }\end{array}$ & $\begin{array}{c}\text { Pangola grass } \\
\text { (Digitaria decumbens) }\end{array}$ \\
\cline { 3 - 4 } & 1 & 1 and 2 & 3 \\
\hline OM (g/kg DM) & 931 & 924 & 910 \\
Nitrogen & 6.2 & 7.9 & 12.0 \\
Sulphur & 1.0 & 1.2 & 1.4 \\
Cell-wall-constituents & 837 & 770 & 814 \\
\hline \hline
\end{tabular}

DM, dry matter.

Table 2. Expt 1. Dry matter intakes of steers given Spear grass (Heteropogon contortus) or Pangola grass (Digitaria decumbens), unsupplemented or supplemented (Mean values with their standard errors; no. of animals in parentheses)

\begin{tabular}{|c|c|c|c|c|c|c|c|c|}
\hline \multirow[t]{3}{*}{. } & \multicolumn{4}{|c|}{ Unsupplemented } & \multicolumn{4}{|c|}{ Supplemented } \\
\hline & \multicolumn{2}{|c|}{$\begin{array}{l}\text { Hereford } \\
\text { (6) }\end{array}$} & \multicolumn{2}{|c|}{$\begin{array}{l}\text { Brahman } \\
(6)\end{array}$} & \multicolumn{2}{|c|}{$\begin{array}{l}\text { Hereford } \\
\quad(6)\end{array}$} & \multicolumn{2}{|c|}{$\begin{array}{l}\text { Brahman } \\
\text { (6) }\end{array}$} \\
\hline & Mean & SE & Mean & SE & Mean & SE & Mean & $\mathrm{SE}$ \\
\hline Spear grass $(\mathrm{kg} / \mathrm{d})$ & $3 \cdot 0$ & $0 \cdot 24$ & $3 \cdot 0$ & $0 \cdot 17$ & 3.6 & 0.07 & $2 \cdot 9$ & $0 \cdot 31$ \\
\hline Spear grass ( $\mathrm{g} / \mathrm{kg}$ fasted $\mathrm{BW}$ ) & $11 \cdot 3$ & $0 \cdot 90$ & 11.8 & 0.89 & $14 \cdot 0$ & $0 \cdot 35$ & $10 \cdot 6$ & $1 \cdot 10$ \\
\hline Pangola grass $(\mathrm{kg} / \mathrm{d})$ & $5 \cdot 4$ & $0.23 *$ & $5 \cdot 0$ & $0 \cdot 26$ & 7.6 & $0 \cdot 23^{*}$ & 5.7 & $0 \cdot 42$ \\
\hline Pangola grass ( $\mathrm{g} / \mathrm{kg}$ fasted $\mathrm{BW})$ & 17.8 & $1.03^{*}$ & $16 \cdot 1$ & $0 \cdot 61$ & $25 \cdot 2$ & $0.98 *$ & $18 \cdot 5$ & 1.00 \\
\hline
\end{tabular}

BW, body-weight.

* Five animals only.

al. 1968), cell-wall-constituents by the method of Van Soest \& Wine (1967) and total S by the method of Mottershead (1971). Osmotic pressure was determined by freezing point depression.

\section{Statistical analysis}

The results of the experiments were subjected to analyses of variance. The third experiment was analysed as a split-plot design with animals as main plots and treatments as sub-plots. Period effects were removed by covariance.

\section{RESULTS}

The chemical compositions of the hays are shown in Table 1.

\section{Expt 1. Voluntary food intake}

Unsupplemented Pangola grass was eaten in greater amounts than Spear grass (11.6 $v$. $17.0 \mathrm{~g} / \mathrm{kg}$ body-weight) (Table 2). There was no significant difference between breeds in intake of either of the unsupplemented diets. When both diets were supplemented with rumen-degradable $\mathrm{N}$ and $\mathrm{S}$, the intake by Herefords was significantly $(P<0.05)$ greater than that by Brahmans. The breed $\times$ treatment interaction was significant $(P<0.05)$ for 


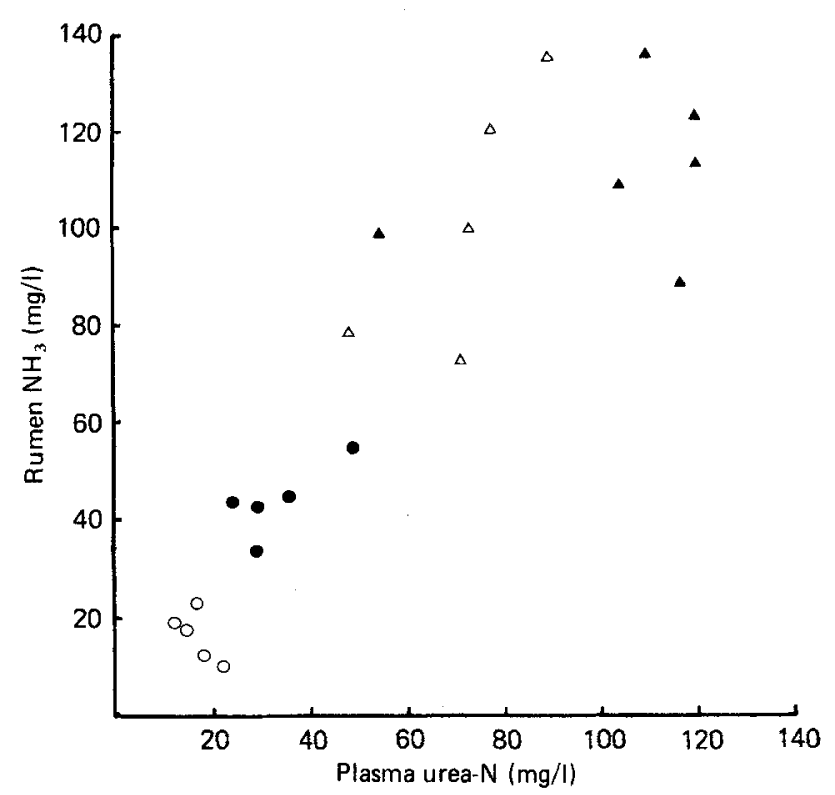

Fig. 1. Expt 1. Relation between plasma urea-nitrogen concentration and rumen ammonia concentration in steers given Pangola grass (Digitaria decumbens), unsupplemented or supplemented. $\bigcirc$, Unsupplemented, Herefords; - , unsupplemented, Brahmans; $\triangle$, supplemented, Herefords; $\boldsymbol{\Delta}$, supplemented, Brahmans. One Brahman unsupplemented value is missing.

both feeds, mainly because the magnitude of the response to supplementation was greater in Herefords. Herefords increased their intake of Pangola grass by $42 \%$ and Brahmans by $15 \%$, the within breed treatment effect being significant for both breeds (Herefords $P<0.001$, Brahmans $P<0.05)$. By contrast only Herefords significantly $(P<0.05)$ increased their intake $(24 \%)$ when Spear grass was supplemented with $\mathrm{N}$ and $\mathrm{S}$. The comparisons between unsupplemented and supplemented diets are confounded with time. However, it is reasonable to conclude that the observed increases in intake were in response to the provision of supplements. Daily intakes in all animals were stable on the unsupplemented diets and increased to stable levels in all animals soon after supplementation commenced.

Rumen $\mathrm{NH}_{3}$ concentrations and plasma urea-N concentrations for both breeds fed on the unsupplemented and supplemented Pangola grass diets are shown in Fig. 1. The relation was positive. On the unsupplemented diet Brahmans had higher rumen- $\mathrm{NH}_{3}$ concentrations and higher plasma urea- $\mathrm{N}$ concentrations than Herefords. Both differences were statistically significant $(P<0.001)$. When the diet was supplemented, the mean rumen- $\mathrm{NH}_{3}$ concentrations were similar in each breed $(101$ and $112 \mathrm{mg} / \mathrm{l}$ for Brahmans and Herefords respectively) but plasma urea-N concentrations were still significantly $(P<0.05)$ higher in Brahmans $(104 \mathrm{mg} / \mathrm{l})$ than in Herefords $(72 \mathrm{mg} / \mathrm{l})$.

\section{Expt 2. Digestion and rumen characteristics of steers fed on Pangola grass}

There was no significant difference between breeds in OM intake or OM digestibility (Table 3). Rumen volumes and rumen osmotic pressures were similar between breeds but mean retention time of fluid was significantly $(P<0.01)$ shorter $(5 \mathrm{~h})$ and hence rumen-fluid dilution rate greater in Brahmans than in Herefords. 
Table 3. Expt 2. Intake, digestion and rumen characteristics of steers fed on unsupplemented Pangola grass (Digitaria decumbens) hay

(Mean values with their standard errors; no. of animals in parentheses)

\begin{tabular}{|c|c|c|c|c|}
\hline & \multicolumn{2}{|c|}{$\begin{array}{l}\text { Hereford } \\
\text { (6) }\end{array}$} & \multicolumn{2}{|c|}{$\begin{array}{l}\text { Brahman } \\
\text { (6) }\end{array}$} \\
\hline & Mean & SE & Mean & SE \\
\hline Organic matter $(\mathrm{OM})$ intake $(\mathrm{g} / \mathrm{kg}$ BW per $\mathrm{d})$ & $15 \cdot 1^{\mathrm{a}}$ & 0.66 & $15 \cdot 0^{\mathrm{a}}$ & 0.74 \\
\hline OM digestibility & $0.57^{\mathrm{a}}$ & 0.136 & $0.58^{\mathrm{a}}$ & 0.095 \\
\hline Water intake (ml/kg BW per d) & $56^{\mathrm{a}}$ & $5 \cdot 8$ & $48^{\mathrm{a}}$ & 1.9 \\
\hline Urine volume $(\mathrm{ml} / \mathrm{kg} \mathrm{BW}$ per $\mathrm{d})$ & $16^{\mathrm{a}}$ & $1 \cdot 5$ & $16^{\mathrm{a}}$ & $1 \cdot 2$ \\
\hline Rumen volume (litres) & $49^{\mathrm{a}}$ & $5 \cdot 4$ & $49^{\mathrm{a}}$ & $4 \cdot 4$ \\
\hline Mean retention time of fluid (h) & $17 \cdot 5^{\mathrm{a}}$ & 1.07 & $12 \cdot 7^{\mathrm{b}}$ & 0.62 \\
\hline Rumen dilution rate $(\% / \mathrm{h})$ & $5 \cdot 8^{\mathrm{a}}$ & $0 \cdot 30$ & $7.9^{\circ}$ & 0.39 \\
\hline Rumen osmolality (mosmol/kg) & $252^{\mathrm{a}}$ & $6 \cdot 7$ & $252^{\mathrm{a}}$ & 6.0 \\
\hline
\end{tabular}

BW, body weight.

a, b Mean values with different superscript letters within the same horizontal row were significantly different $(P<0.05)$.

Table 4. Expt 3. Intake, digestion and rumen characteristics of steers fed on Pangola grass (Digitaria decumbens) hay alone or supplemented with nitrogen and sulphur (Mean values with their standard errors; residual df in parentheses)

\begin{tabular}{|c|c|c|c|c|c|c|c|c|}
\hline & \multicolumn{4}{|c|}{ Treatment } & \multicolumn{4}{|c|}{ Breed } \\
\hline & \multicolumn{2}{|c|}{ Unsupplemented } & \multicolumn{2}{|c|}{ Supplemented } & \multicolumn{2}{|c|}{ Hereford } & \multicolumn{2}{|c|}{ Brahman } \\
\hline & Mean & $\mathrm{SE}$ & Mean & $\mathrm{SE}$ & Mean & $\mathrm{SE}$ & Mean & SE \\
\hline $\begin{array}{l}\text { Organic matter (OM) intake } \\
(\mathrm{g} / \mathrm{kg} \mathrm{BW} \text { per } \mathrm{d})\end{array}$ & $17 \cdot 1$ & 0.22 & $18 \cdot 1^{*}$ & $0 \cdot 22(7)$ & $17 \cdot 2$ & 0.66 & $18 \cdot 0$ & $0.61(9)$ \\
\hline$O M$ digestibility & 0.55 & 0.007 & 0.56 & $0.007(7)$ & 0.55 & 0.009 & 0.55 & $0.008(9)$ \\
\hline $\begin{array}{l}\text { Water intake } \\
(\mathrm{ml} / \mathrm{kg} \mathrm{BW} \text { per } \mathrm{d})\end{array}$ & 58 & $1 \cdot 3$ & $67^{*}$ & $1 \cdot 2(4)$ & 63 & 3.5 & 62 & $3 \cdot 4(7)$ \\
\hline Rumen volume (litres) & 48 & $3 \cdot 9$ & 44 & $4 \cdot 1(4)$ & 40 & $5 \cdot 0$ & 52 & $4 \cdot 7(7)$ \\
\hline Mean retention time (h) & $10 \cdot 2$ & 0.32 & $9 \cdot 9$ & $0.55(4)$ & $10 \cdot 2$ & 0.76 & $9 \cdot 8$ & $0.72(7)$ \\
\hline $\begin{array}{l}\text { Rumen fluid dilution rate } \\
(\% / \mathrm{h})\end{array}$ & $10 \cdot 4$ & 0.88 & $10 \cdot 0$ & $0.92(4)$ & $9 \cdot 7$ & 0.92 & $10 \cdot 8$ & $0.87(7)$ \\
\hline $\begin{array}{l}\text { Rumen-NH } \\
(\mathrm{mg} / \mathrm{l})\end{array}$ & 36 & $5 \cdot 6$ & $126 * * *$ & $5.9(6)$ & 88 & $7 \cdot 6$ & 74 & $7 \cdot 3(8)$ \\
\hline $\begin{array}{l}\text { Rumen osmolality } \\
\text { (mosmol } / \mathrm{kg})\end{array}$ & 233 & 6.8 & 271 & $6 \cdot 4(1)$ & 254 & $4 \cdot 4$ & 250 & $4 \cdot 1(7)$ \\
\hline
\end{tabular}

BW, body-weight.

* $P<0.05,{ }^{* * *} P<0.001$.

\section{Expt 3. Effect of supplementation with $N$ and $S$ on intake, digestion and rumen} characteristics of steers fed on Pangola grass

The Pangola grass given in this experiment had a higher $\mathrm{N}$ concentration than the hay given in Expts 1 and 2 (Table 1). OM intake, water intake and rumen $\mathrm{NH}_{3}$ concentration were significantly increased by supplementation, but the breed effect was not significant. There were no significant differences for treatments, breeds or periods in the analyses of rumen volume, mean retention time or rumen osmolarity. The lack of a breed difference in mean 
retention time is in contrast to the differences observed in Expt 2. There was no evidence of treatment by breed interactions. Treatment and breed means, adjusted for covariates, are given in Table 4.

\section{DISCUSSION}

This study examined the utilization of low-quality forages by Bos indicus and Bos taurus cattle. It showed that the intakes of Brahman and Hereford steers, free from environmental stress, were similar when intakes were depressed by nutrient insufficiency. When nutrients were provided, there was evidence from one experiment, but not from another, that intakes were higher in Hereford steers. There are reports that Bos taurus cattle have higher intakes than Bos indicus of good and medium quality forage diets (Frisch \& Vercoe, 1969, 1977).

The different intake responses, both within and between cattle genotypes, when the various diets were supplemented with $\mathrm{N}$ and $\mathrm{S}$, may be explained in terms of: (1) the breed difference in rumen- $\mathrm{NH}_{3}$ concentrations on the unsupplemented diets, (2) the different abilities of the two breeds to consume diets on which rumen function is not limited by nutrient deficiency, (3) the deficit between the $\mathbf{N}$ and $\mathbf{S}$ supplied to the rumen by the diet and the rumen requirement for $\mathrm{N}$ and $\mathrm{S}$, (4) the resistance of the dietary forage to digestion when the supply of nutrients was adequate.

There is a relation between the incorporation of $\mathrm{N}$ into microbial protein and the amount of dietary OM fermented in the rumen which is approximately $30 \mathrm{~g} \mathrm{~N} / \mathrm{kg}$ digestible $\mathrm{OM}$ (Agricultural Research Council, 1980). Therefore, in the situation where there were $\mathrm{N}$ and $\mathrm{S}$ deficiencies (unsupplemented diets), the digestion of $\mathrm{OM}$ would have been limited by microbial activity. On the other hand, when the rumen was adequately supplied with nutrients, the disappearance of OM would have been limited by the rate at which the microbial population gained access to, and digested, that portion of the plant cell which was potentially digestible. Factors (1), (3) and (4), mentioned previously, exercised control on intake by limiting rumen function through nutrient deficiency or by determining the rate of disappearance of OM that could be achieved by digestion when the nutrient supply was adequate.

It is suggested that the breed differences in rumen- $\mathrm{NH}_{3}$ concentration in favour of the Brahmans on the low- $\mathrm{N}$ unsupplemented diets may be explained in terms of their superior ability to recycle endogenous $\mathrm{N}$ to the rumen. They consistently had higher plasma urea- $\mathrm{N}$ concentrations and higher rumen- $\mathrm{NH}_{3}$ concentrations at the same rumen volume than Herefords on unsupplemented diets and higher concentrations of plasma urea, even when the diet was supplemented with $\mathrm{N}$ and $\mathrm{S}$. A positive relation between concentrations of plasma urea- $\mathrm{N}$ and rumen $\mathrm{NH}_{3}$ (Vercoe, 1969) and plasma urea concentration and urea entry rate into the rumen (Kennedy, 1980) has been demonstrated. The results of Kennedy (1980) also suggest that on roughage diets most of the return of $N$ to the rumen is via the saliva rather than transfer across the rumen wall. The difference in $\mathrm{NH}_{3}$ concentration between breeds in the present study was more marked when the low- $\mathrm{N}$ diets were given. When the dietary $\mathbf{N}$ supply was almost adequate, as assessed by the small intake response to supplementation in Expt 3, the difference in $\mathrm{NH}_{3}$ concentrations was not significant.

The intake capabilities of the two breeds on diets which permit normal rumen function also influenced intake response by setting the maximum intake and, hence, the magnitude of the response that each breed could achieve once the nutrient deficiency was overcome. It has been shown that, when the intake of a diet was limited by an inadequacy of $\mathrm{N}$, incremental increases in the amount of $\mathrm{N}$ supplied as a supplement were associated with increases in voluntary food intake until the $\mathrm{N}$ supply was adequate (Coombe \& Tribe, 1963). In the previous study (Hunter \& Siebert, 1985) it was found that increases in rumen digestion rate of the lower- $\mathrm{N}$ Pangola grass did not occur at $\mathrm{NH}_{3}$ concentrations above $60-80 \mathrm{mg} / \mathrm{l}$. Thus the large differential intake response to supplementation between breeds on both the 
Spear grass and this lower-N Pangola grass diet was due, at least in part, to the extent to which a deficiency of $\mathrm{N}$ in the rumen was limiting intake of the unsupplemented diets. For example, when the diet was low-N Pangola grass, rumen function and intake would have been more seriously impaired in the Hereford $\left(\mathrm{NH}_{3} 16 \mathrm{mg} / \mathrm{l}\right)$ than in the Brahman steers $\left(\mathrm{NH}_{3} 40 \mathrm{mg} / 1\right)$. Therefore a greater response in Herefords was recorded when the $\mathrm{N}$ deficiency was corrected. If this were the only mechanism that operated however, intakes of both breeds after supplementation would have been similar. This was not the case. The other part of the differential intake response lies with the ability of the British breed to eat more of a good-quality diet than Brahman type cattle (Frisch \& Vercoe, 1969, 1977). Once the nutrient deficiencies were overcome, this was expressed. It may well be that the higher intake potential of the Herefords means that they can maintain the same intake as Brahmans on unsupplemented diets even though the rate of disappearance of OM by rumen digestion is less than that in Brahmans (Hunter \& Siebert, 1985). It must be pointed out that when the higher-N Pangola grass was supplemented (Expt 3 ) the Herefords did not have higher intakes. The reason is not known and in a subsequent study at this laboratory with the same steers given a lucerne-based diet (adequate $\mathrm{N}$ ) the Herefords did eat more than the Brahmans.

The deficit between the dietary supply of $\mathrm{N}$ and $\mathrm{S}$ to the rumen and the rumen requirement for $\mathrm{N}$ and $\mathrm{S}$ also had an effect on the intake response to supplementation. This effect is best illustrated by comparing the intake response to supplementation when different harvests of Pangola grass hay with different $N$ and $S$ concentrations $(7.9$ and $12.0 \mathrm{~g} \mathrm{~N} / \mathrm{kg} \mathrm{OM}$ ) were given. The greater intake response in both breeds was recorded on the lower- $\mathrm{N}$ diet. The reasons for this are similar to those elaborated above in connection with rumen- $\mathrm{NH}_{3}$ concentration which is partly a function of the $\mathrm{N}$ supplied to the rumen by the diet. The $\mathrm{NH}_{3}$ concentrations measured in Expts 1 and 3 on the Pangola grass diets cannot be compared directly because of the different sampling schedules for rumen fluid. For Expt 1 a single rumen fluid sample was collected at the end of a twice a day feeding cycle whereas, in Expt 3, samples were collected over a $14 \mathrm{~h}$ period of the twenty-four times daily feeding cycle.

The resistance of the forage to digestion also may have affected the intake response to supplementation. Hunter \& Siebert (1985) studied the rumen digestion of the Spear grass and the lower- $\mathrm{N}$ Pangola grass hays both before and after supplementation with $\mathrm{N}$ and $\mathrm{S}$. They found that the rate of rumen digestion of Pangola grass, although not Spear grass, was sigificantly increased by supplementation. They argued that Spear grass, especially the cell wall fraction, was highly resistant to digestion even in the presence of adequate $\mathrm{N}$ and S. On the other hand the Pangola grass hay was potentialy more digestible (Hunter \& Siebert, 1985) and, when digestion was not affected by an inadequacy of essential nutrients, this higher potential digestion rate was achieved. Thus, supplementation resulted in a smaller increase in removal of Spear grass than Pangola grass residues from the rumen by digestion, allowing for only a small increase in feed intake of Spear grass (Thornton \& Minson, 1972). This effect presumably overrode any possible differential intake response that may have been associated with the small differences in $\mathrm{N}$ concentrations of the hays (g/kg OM; Spear grass 6.2, Pangola grass 7.9).

The lower mean retention time of rumen fluid in Brahman steers fed on the lower- $\mathrm{N}$ Pangola grass when the rumen was deficient in $\mathrm{N}$ and $\mathrm{S}$ was associated with the higher rates of digestion found in Brahman steers fed on the same unsupplemented hay (Hunter \& Siebert, 1985). Likewise, the similarity of mean retention times in the two breeds in the subsequent experiment when the $\mathrm{N}$ and $\mathrm{S}$ supply in the rumen was enhanced was in accord with the similarity of digestion rates when the diet was supplemented (Hunter \& Siebert, 1985).

The present study has sought to provide an explanation for the variable intake responses 
that have been recorded between breeds of cattle when low-quality roughages are supplemented with rumen-degradable $\mathbf{N}$ and $\mathrm{S}$. Intake response is the result of a number of interacting factors which include the breed of animal to which the roughage is given as well as the chemical composition and digestion attributes of the roughage itself. The breed effect is mediated via the intake capability of the breed on good quality diets and its ability to maintain elevated rumen $\mathrm{NH}_{3}$ concentrations on poor-quality diets. The most important characteristic of the roughage affecting intake response to supplementation is the rate at which its $\mathrm{OM}$ is digested in the rumen.

The authors thank $\mathrm{Mr} \mathrm{C}$. R. Holmes for surgical preparation of the cattle and $\mathrm{Mr}$ T. Magner and Mr W. D. Sim for technical assistance.

\section{REFERENCES}

Agricultural Research Council (1980). The Nutrient Requirements of Ruminant Livestock. Farnham Royal: Commonwealth Agricultural Bureaux.

Binnerts, W. T., van't Klooster, A. Th. \& Frens, A. M. (1968). Veterinary Record 82, 470.

Coombe, J. B. \& Tribe, D. E. (1963). Australian Journal of Agricultural Research 14, $70-92$.

Frisch, J. E. \& Vercoe, J. E. (1969). Australian Journal of Agricultural Research 20, 1189-1195.

Frisch, J. E. \& Vercoe, J. E. (1977). Animal Production 25, 343-358.

Hunter, R. A. \& Siebert, B. D. (1980). Australian Journal of Agricultural Research 31, 1037-1047.

Hunter, R. A. \& Siebert, B. D. (1985). British Journal of Nutrition 53, 637-648

Kennedy, P. M. (1980). British Journal of Nutrition 43, 125-140.

Logsdon, E. E. (1960). Annals of the New York Academy of Science 87, 801-807,

Marsh, W. H., Fingerhut, B. \& Miller, H. (1965). Clinical Chemistry 11, 624-627.

Mottershead, B. E. (1971). Laboratory Practice 20, 483-491.

Thornton, R. F. \& Minson, D. J. (1972). Australian Journal of Agricultural Research 23, 871-877.

Van Soest, P. J. \& Wine, R. H. (1967). Journal of the Association of Official Agricultural Chemists 50, 50-55.

Vercoe, J. E. (1969), Australian Journal of Agricultural Research 20, 191-197.

Weston, R. H. \& Hogan, J. P. (1967). Australian Journal of Agricultural Research 18, 789-801. 